\title{
Interaction between the Cholecystokinin and Endogenous Cannabinoid Systems in Cued Fear Expression and Extinction Retention
}

\author{
Mallory E Bowers' and Kerry J Ressler*, I,2 \\ 'Behavioral Neuroscience, Department of Psychiatry and Behavioral Sciences, Howard Hughes Medical Institute, Emory University, Yerkes \\ Research Center, Atlanta, GA, USA; ${ }^{2}$ Howard Hughes Medical Institute, Emory University, Atlanta, GA, USA
}

\begin{abstract}
Post-traumatic stress disorder (PTSD) is thought to develop, in part, from improper inhibition of fear. Accordingly, one of the most effective treatment strategies for PTSD is exposure-based psychotherapy. Ideally, neuroscience would inform adjunct therapies that target the neurotransmitter systems involved in extinction processes. Separate studies have implicated the cholecystokinin (CCK) and endocannabinoid systems in fear; however, there is a high degree of anatomical colocalization between the cannabinoid I receptor $(\mathrm{Cnrl})$ and $\mathrm{CCK}$ in the basolateral amygdala (BLA), a brain region critical for emotion regulation. Although most research has focused on GABA and GABAergic plasticity as the mechanism by which $\mathrm{Cnrl}$ mediates fear inhibition, we hypothesize that a functional interaction between $\mathrm{Cnrl}$ and CCKB receptor (CCKBR) is critical for fear extinction processes. In this study, systemic pharmacological manipulation of the cannabinoid system modulated cued fear expression in C57BL/6) mice after consolidation of auditory fear conditioning. Knockout of the CCKBR, however, had no effect on fear- or anxiety-like behaviors. Nonetheless, administration of a Cnrl antagonist increased freezing behavior during a cued fear expression test in wild-type subjects, but had no effect on freezing behavior in CCKBR knockout littermates. In addition, we found that Cnrl-positive fibers form perisomatic clusters around CCKBR-positive cell bodies in the BLA. These CCKBR-positive cells comprise a molecularly heterogenous population of excitatory and inhibitory neurons. These findings provide novel evidence that $\mathrm{Cnrl}$ contributes to cued fear expression via an interaction with the CCK system. Dysfunctional CnrlCCKBR interactions might contribute to the etiology of, or result from, fear-related psychiatric disease.
\end{abstract}

Neuropsychopharmacology (20I5) 40, 688-700; doi:I0.1038/npp.20I4.225; published online 24 September 20I4

\section{INTRODUCTION}

Evidence suggest that post-traumatic stress disorder (PTSD) and other fear-related disorders might manifest from dysfunction in the inhibition, or extinction, of fear (Myers and Davis, 2007). One of the most effective treatment strategies for fear-related disorders is exposure therapy, in which the feared object, context, or memory is repeatedly presented or recalled until fear is inhibited. Although exposure therapy is an often prescribed and efficacious treatment, its mechanisms are still poorly understood. Extinction of conditioned fear in animal models can be used as an analog of exposure therapy to try to dissect the mechanisms of fear learning. In this way, translational approaches can be used to augment currently prescribed therapies.

The exposure therapy/extinction literature demonstrates a critical role played by the amygdala in fear learning (Quirk

\footnotetext{
*Correspondence: Dr KJ Ressler, Behavioral Neuroscience, Department of Psychiatry and Behavioral Sciences, Howard Hughes Medical Institute, Emory University, Yerkes Research Center, 954 Gatewood Dr, NE Atlanta, GA 30329, USA, Tel: +I 404727 7739, Fax: + 404727 8070, E-mail: kressle@emory.edu Received 28 April 2014; revised 10 July 2014; accepted 2 August 2014; accepted article preview online I September 2014
}

et al, 1995, 2003; Muller et al, 1997; LeDoux, 2000). The amygdala processes emotionally relevant stimuli via the interactions of neurotransmitters (Bowers et al, 2012) and it is highly enriched in a number of neuromodulators, in particular the endogenous cannabinoids and cholecystokinin (CCK) (Larsson and Rehfeld, 1979; Herkenham et al, 1990). Studies of the cannabinoid system suggest that the cannabinoid 1 receptor ( $\mathrm{Cnr} 1$, also abbreviated $\mathrm{Cb} 1$ ) and the endogenous cannabinoids are critical for emotion, pain, feeding, addiction, anxiety, and memory (Richard et al, 2009; Mechoulam and Parker, 2013). Global knockout or systemic antagonism of $\mathrm{Cnrl}$ increases freezing behavior during a fear expression test and causes a persistent blockade of within-session extinction of cued fear (Marsicano et al, 2002; Reich et al, 2008). Data demonstrate an increase in the synthesis of the two major endocannabinoids, anandamide (AEA) and 2-arachidonoylglycerol (2-AG), in the basolateral amygdala (BLA) after a short extinction test (Marsicano et al, 2002).

Intriguingly, Cnrl shows a high degree of colocalization with CCK in the BLA at the mRNA and protein level (McDonald and Mascagni, 2001; Chhatwal et al, 2009). CCK is one of the most highly expressed central nervous system (CNS) neuropeptides, particularly within limbic structures (Vanderhaeghen et al, 1975; Mascagni and McDonald, 
2003). There are two CCK receptor isoforms-CCKAR and CCKBR (IUPHAR-CCK1/2) (Hill et al, 1987; Mercer and Beart, 2004). A number of studies demonstrate a role for CCK in fear and anxiety, primarily through activation of $\mathrm{G}_{\mathrm{q}}$-coupled CCKBR (de Montigny, 1989; Bradwejn et al, 1991; Rasmussen et al, 1993; Josselyn et al, 1995; Frankland et al, 1996, 1997; Areda et al, 2006; Joseph et al, 2013). Interestingly, CCK and the endocannabinoids seem to engender opposite fear responses. CCK elicits panic attacks in humans, and elevates anxiety-like behavior and the expression of cued fear in rodents (de Montigny, 1989; Bradwejn et al, 1990, 1991; Chhatwal et al, 2009). In contrast, increasing endocannabinoid tone enhances extinction of cued fear and fear-potentiated startle, and can be anxiolytic (Chhatwal et al, 2005; Gunduz-Cinar et al, 2013). Notably, some data suggest that Cnr1 activation leads to an inhibition of CCK release in the hippocampus (Beinfeld and Connolly, 2001).

Although most research has focused on GABA and GABAergic plasticity as the mechanism by which Cnrl mediates fear inhibition (Katona et al, 2001; Marsicano et al, 2002; Azad et al, 2003, 2004; Kamprath et al, 2011; Lin et al, 2011; Uriguen et al, 2011), we hypothesize that the anatomical colocalization of CCK and Cnr1 indicates a potential functional relationship that may be critical for extinction learning. We propose that activation of presynaptic Cnrl during extinction causes a decrease in probability of release (Pertwee, 1997; Schlicker and Kathmann, 2001) at GABAergic CCK terminals, inhibiting CCK transmission. Thus, by preventing initiation of CCKactivated fear circuitry via CCKBR, Cnr1 promotes inhibition of freezing during cued fear extinction. Here, we test the hypothesis that CCKBR knockout mice will exhibit enhanced extinction of cued fear. Furthermore, we propose that normal blockade of extinction in wild-type mice by a Cnr1 antagonist (Marsicano et al, 2002) will not be observed in CCKBR knockout littermates, as we hypothesize that Cnrl is upstream of CCKBR.

\section{MATERIALS AND METHODS}

\section{Animals}

Adult male C57BL/6J and 129-Cckbr ${ }^{\text {tm1Kpn }} / \mathrm{J}$ (Jackson Laboratories) 8 to 12 weeks old were group housed in a temperature-controlled $\left(24^{\circ} \mathrm{C}\right)$ animal colony, with ad libitum access to food and water, on a 12-h light-dark cycle. Experimental subjects were genotyped by PCR using primers olMR6447 (reverse: 5'-CTTAGCCTGGACAGAGAA GC-3'), olMR6916 (knockout forward: 5'-CTTGGGTGGA GAGGCTAT TC-3'), and olMR7283 (wild type forward: 5'-CCAAGCTGCTGGCTAAGAAG-3'). Homozygous CCKBR knockout and wild-type littermates from in-house heterozygous breeding pairs were used for experiments. All behavioral procedures were performed during the light cycle. Separate cohorts of transgenic mice were tested on elevated plus maze, open field test, shock reactivity and associative fear learning, and extinction paradigms. Separate cohorts of C57BL/6J were tested for an effect of systemic URB597 on anxiety-like and fear behavior on the open field and on a cued fear extinction test.

\section{Behavior}

Elevated plus maze. Subjects were handled once per day for two days prior to testing. Subjects were placed in the elevated plus maze apparatus to explore for $5 \mathrm{~min}$ in dim lighting. Behavior was hand-scored for time on open arms, time on closed arms, time in center, and number of entries into the open and closed arms.

Open-field test. Subjects were handled once per day for 2 days before testing. The open field consisted of an open box $(27.9 \mathrm{~cm} \times 27.9 \mathrm{~cm})$ made of PLEXIGLAS. Subjects were placed in the apparatus to explore for $10 \mathrm{~min}$, and then returned to their home cage. All testing was conducted under standard room lighting. Activity data were analyzed using the Open Field Activity Software (Med Associates, St Albans, VT) for locomotor activity (distance traveled in centimeters over $10 \mathrm{~min}$ ) and anxiety-like behavior (time spent in center of chamber in seconds, where center is defined as $6 \mathrm{~cm}$ from the perimeter of chamber walls).

Shock reactivity. Shock reactivity was assayed by averaging the immediate shock reactivity to five $0.5 \mathrm{~mA}$ shocks separated by a 5 -min inter-trial interval (Med Associates).

Associative fear conditioning and extinction. All mice were handled once per day for 2 days and then pre-exposed once to the test chambers (Med Associates) the day before training. Fear conditioning and extinction experiments were performed in different contexts, where light, odor, and tactile cues were shifted. FreezeFrame and FreezeView software (Coulbourn Instruments, \#ACT-100, Allentown, PA) were used to examine percent time spent freezing during tone presentations as a measure of fear behavior.

For the Cnr1 antagonist (SR141716A) and fatty acid amide hydrolase (FAAH) inhibitor (URB597) experiments, C57BL/6J mice received 2 days of 10 paired conditioned stimulus (CS) tones $(30 \mathrm{~s}, 6 \mathrm{kHz}, 75-80 \mathrm{~dB})$, which coterminated with the unconditioned stimulus (US) shock (500 ms, $1.0 \mathrm{~mA})$. Three days after fear conditioning, subjects were presented with a brief fear expression test of three CS trials ('grouping'). Average freezing in response to the three CS trial tests was used to organize subjects into separate groups. The following day, subjects were administered vehicle or drug and exposed to $10 \mathrm{CS}$ trials (30 s tone, $30 \mathrm{~s} \mathrm{ITI)}$ to assess cued fear expression. Twenty-four hours later, subjects were tested to $15 \mathrm{CS}$ trials ( $30 \mathrm{~s}$ tone, $30 \mathrm{~s} \mathrm{ITI),}$ off drug, to assess extinction retention. In the SR141716A experiment, one and two subjects were removed from analysis on extinction retention and fear expression/ extinction training days, respectively, as subjects were obscured from the camera and thus not able to be accurately scored.

For experiments with CCKBR transgenic mice (129S1 background strain), subjects received 1 day of 5 CS-US pairings. Transgenic subjects received a shorter fear conditioning protocol and longer extinction training, as evidence suggests that $129 \mathrm{~S} 1$ mice exhibit greater freezing behavior during fear conditioning, extinction, and extinc-

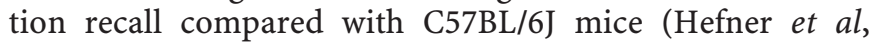
2008). Three days after fear conditioning, subjects were presented with a brief fear expression test of three CS trials 
('grouping'). Average freezing in response to the three CS trial tests was used to organize subjects into separate groups. The following day, subjects were administered $30 \mathrm{CS}$ trials ( $30 \mathrm{~s}$ tone, $30 \mathrm{~s}$ ITI). Two experiments were conducted with CCKBR transgenic mice. In the first experiment, subjects were not administered drug before cued fear expression/extinction training. In the second experiment, subjects were administered vehicle or $3 \mathrm{mg} / \mathrm{kg}$ SR141716A $20 \mathrm{~min}$ before cued fear expression/extinction training. In both experiments, freezing to the first $10 \mathrm{CS}$ of the 30 CS trials was averaged and compared between groups to dissociate cued fear expression and within-session extinction. Within-session extinction was analyzed by parsing freezing behavior into three 10 CS bins. Average freezing to CS 11-20 and CS 21-30 was normalized to average freezing during CS 1-10. The extinction retention test occurred similarly in test chambers $24 \mathrm{~h}$ later, off drug, where mice were exposed to 15 trials of the $30 \mathrm{~s}$ CS tone (30 s ITI). Extinction retention was defined as average freezing to CS $1-10$ to dissociate retention from withinsession extinction.

\section{Drugs}

The Cnr1 antagonist, SR141716A (Cayman Chemical 9000484), was dissolved in a vehicle of $2.5 \% \mathrm{DMSO} / 0.1 \%$ Tween-80 in saline to yield a final drug concentration of $3 \mathrm{mg} / \mathrm{kg}$. The FAAH inhibitor, URB597 (Sigma U4133), was dissolved in DMSO and then diluted to $10 \%$ to yield final drug concentrations of $0.1,0.3$, and $1 \mathrm{mg} / \mathrm{kg}$. SR141716A and URB597 were systemically administered intraperitoneally (IP) 20 and $30 \mathrm{~min}$, respectively, before extinction training. URB597 was administered separately the open field test.

\section{Immunohistochemistry}

Immunofluorescence experiments were performed on $4 \%$ paraformaldehyde-fixed mouse brain sections derived from three adult mice. Animals were anesthetized with sodium pentobarbital and then transcardially perfused with ice-cold $0.05 \mathrm{M}$ phosphate buffer saline (PBS, $\mathrm{pH}$ 7.4) followed by $20 \mathrm{ml}$ of $4 \%$ paraformaldehyde in PBS. Brains were removed and post-fixed in $4 \%$ paraformaldehyde for $2 \mathrm{~h}$ before being cryoprotected in $30 \%$ sucrose in PBS for $48 \mathrm{~h}$ at $4{ }^{\circ} \mathrm{C}$. Coronal brain sections $(45 \mu \mathrm{m})$ were cut on a Leica CM 3050 S cryostat and stored at $20^{\circ} \mathrm{C}$ in a cryoprotective medium consisting of $25 \%$ glycerol and $30 \%$ ethylene glycol in $0.05 \mathrm{M}$ phosphate buffer until needed. Representative sections were rinsed three times for $10 \mathrm{~min}$ in PBS, permeabilized with $0.5 \%$ Triton-X 100 in PBS, and incubated for $48 \mathrm{~h}$ at $4{ }^{\circ} \mathrm{C}$ with primary antibody in $0.5 \%$ Triton-X/PBS solution (all antibodies cataloged in Table 1). Sections were then rinsed three times for $10 \mathrm{~min}$ in PBS and incubated at room temperature for $2 \mathrm{~h}$ with either Alexa-Fluor 488- or Alexa-Fluor 568-conjugated secondary antibody (1:500, Molecular Probes, Invitrogen, Carlsbad, CA) against the primary antibody's host. Sections were then rinsed two times for $10 \mathrm{~min}$ in PBS and one time for $10 \mathrm{~min}$ in phosphate buffer (PB). Sections were then mounted on glass slides and cover slipped using Mowiol mounting medium. Confocal laser scanning microscopy was used to obtain high-resolution photomicrographs using an Orca R2 cooled CCD camera (Hammamatsu, Bridgewater, NJ) mounted on a Leica DM5500B microscope (Leica Microsystems, Bannockburn, IL).

\section{Statistics}

Statistics were performed using IBM SPSS Statistics 21 software. Two-tailed, one- or two-way repeated-measures analysis of varience (ANOVA), followed by least significant difference (LSD) post hoc comparisons, or Student's $t$-test (two-tailed) for independent samples were used where appropriate, unless otherwise noted. The results are presented as mean + SEM, with $p \leqslant 0.05$ as the statistical measure of significance.

\section{RESULTS}

\section{The Cannabinoid System is Critical for Cued Fear Expression}

To address our overarching hypothesis, we first performed auditory fear conditioning experiments in C57BL/6J mice to assess the role of Cnr1 in extinction learning. SR141716A, a Cnrl antagonist, was administered before cued fear expression/extinction training. At a dose of $3 \mathrm{mg} / \mathrm{kg}$, SR141716A has been shown to be effective at blocking extinction in C57BL/6J mice (Marsicano et al, 2002). In our model, SR141716A treatment significantly increased freezing behavior compared to vehicle group during cued fear expression/extinction training $\left(\mathrm{F}_{1,19}=6.06, \quad p<0.05\right.$, Figure 1a). Vehicle and SR141716A-treated groups did not differ significantly when comparing freezing behavior the following day on an extinction retention test (Figure $1 \mathrm{a}^{\prime}$ ).

We also tested the effect of an FAAH inhibitor, URB597, on cued fear expression/extinction training in a separate experiment. FAAH is an enzyme that catalyzes degradation of anandamide, one of the two major endocannabinoids (Cravatt et al, 1996). We injected URB597 at a dose of 0.1, 0.3 , or $1 \mathrm{mg} / \mathrm{kg}$ before cued fear expression/extinction training. We found that at a dose of $1 \mathrm{mg} / \mathrm{kg}$, URB597treated subjects exhibited a significant decrease in freezing behavior during cued fear expression/extinction training $\left(\mathrm{F}_{3,26}=3.2, p<0.05\right.$, post hoc (LSD): vehicle $v s 1 \mathrm{mg} / \mathrm{kg}$, $p<0.05$, Supplementary Figure S1a). Vehicle- and URB597treated groups did not significantly differ when comparing freezing $24 \mathrm{~h}$ later on an extinction retention test (Supplementary Figure S1a').

\section{Global CCKB Receptor Knockout has no Effect on Baseline Measures of Weight, Shock Reactivity, Locomotion, or Anxiety-Like Behavior}

Next, we examined the role of CCKBR in anxiety-like behavior and baseline measures of weight, shock reactivity, and locomotion. To do this, we tested mice with a targeted mutation of the CCKB receptor, in which insertion of a neomycin selection cassette deleted sequence-encoding transmembrane domains V through VII. No receptor function was detected in a competition binding assay of brains in mutant mice (Langhans et al, 1997). Body weights were not different between genotypes (Figure 2a), and CCKBR knockouts did not exhibit significantly different shock reactivity relative to wild-type littermates (Figure $2 \mathrm{~b}$ ). 
Table I Antibodies Used in Immunohistochemistry Experiments

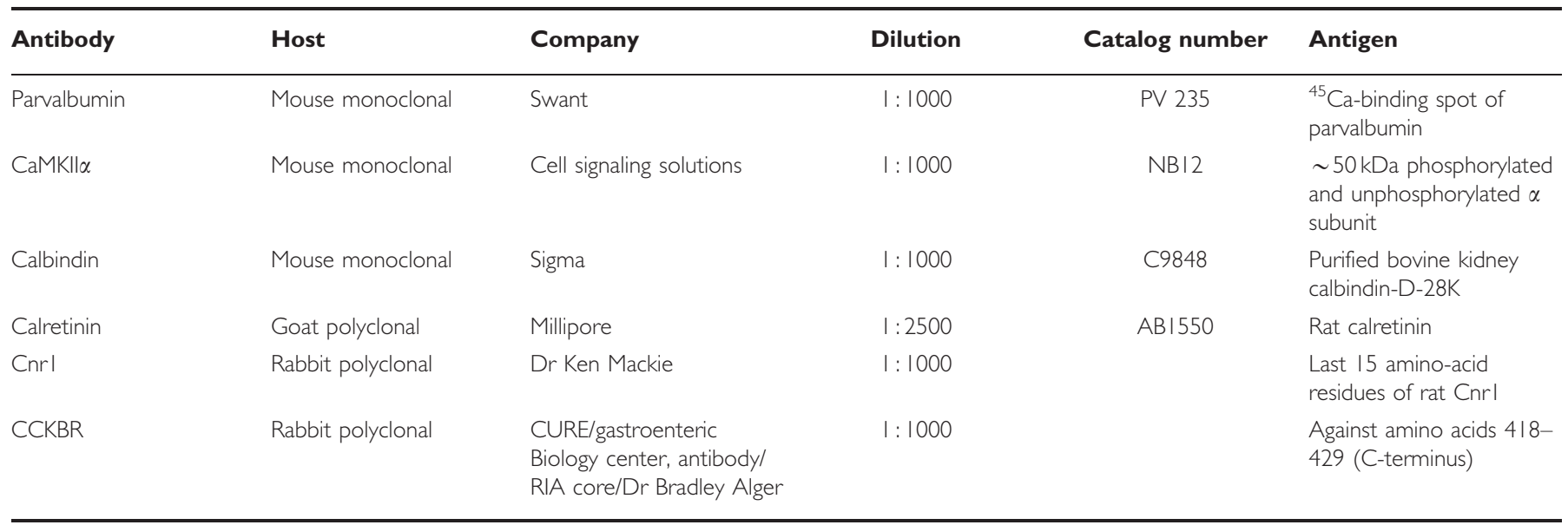

Abbreviations: CaMKII $\alpha$, calcium/calmodulin-dependent protein kinase II alpha; CCK, cholecystokinin; CCKBR, CCKB receptor; Cnrl, cannabinoid I receptor.
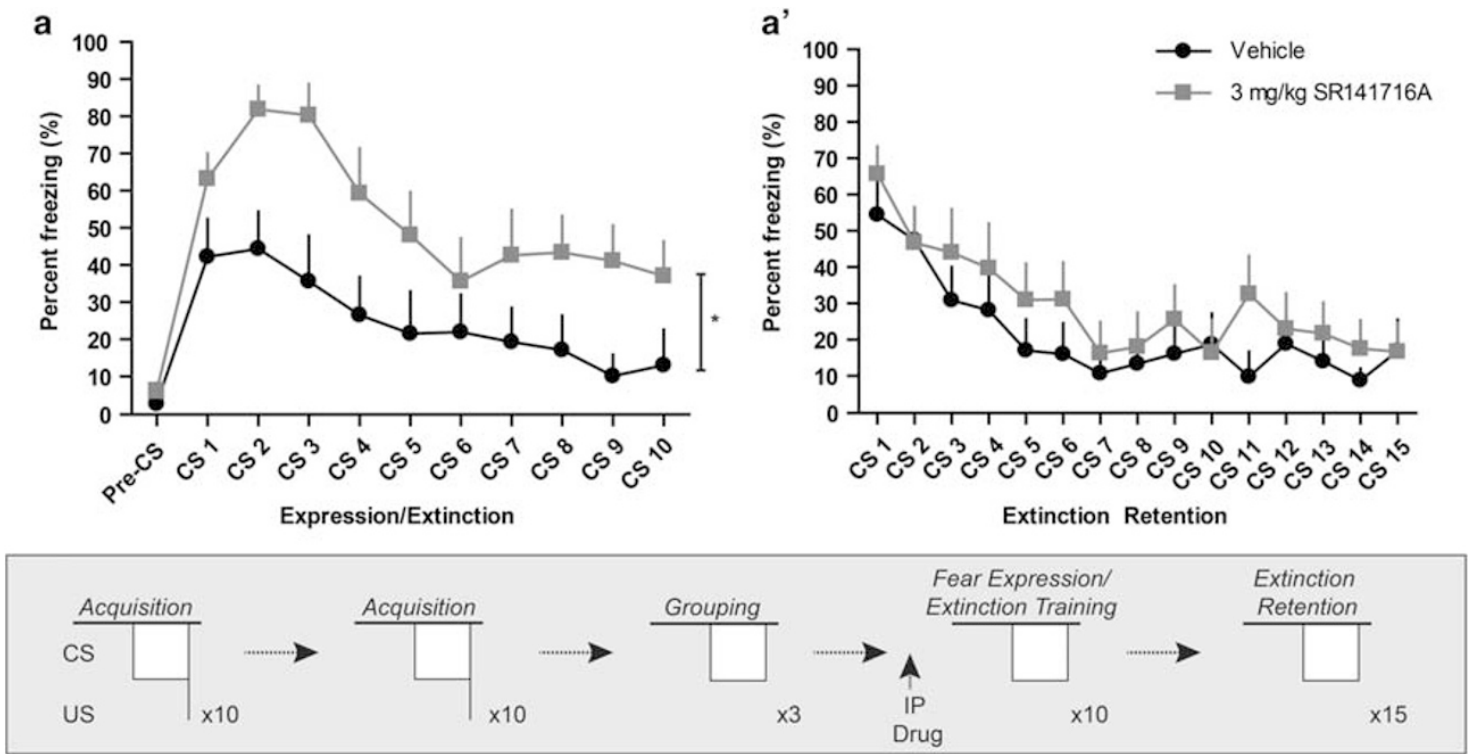

Figure I Manipulation of the cannabinoid system acutely alters cued fear expression. (a) Intraperitoneal (IP) administration of the cannabinoid I receptor (Cnrl) antagonist, SRI4I7I6A, increases freezing during cued fear expression/extinction training. ( $\left.\mathrm{a}^{\prime}\right) 24 \mathrm{~h}$ after drug administration, vehicle- and SRI4I7I6A-administered groups do not exhibit significantly different freezing behavior during an extinction retention test. Average freezing in response to a 3 CS 'grouping' test was used to organize subjects into separate groups (grouping data not shown). Asterisk denotes $p<0.05$, main effect of drug.

Wild type and CCKBR knockout littermates did not significantly differ on a measure of distance traveled during the open-field test (Supplementary Figure S2). In addition, CCKBR knockout mice did not exhibit an anxiety-like phenotype when tested on an open field (Figure 2c) or elevated plus maze (Figure 2d, Supplementary Figure S3).

\section{CCKBR Knockout Mice Exhibit Normal Cued Fear Acquisition, Expression, and Extinction}

Next, we performed auditory fear conditioning and extinction tests to determine whether knockout of CCKBR has an effect on cued fear learning and memory. Wild-type and CCKBR knockout littermates did not exhibit significant differences in freezing behavior during cued fear acquisition (Figure 3a), cued fear expression, or extinction retention
(Figure 3b). Statistical analysis revealed a significant effect of CS bin on freezing $\left(\mathrm{F}_{2,36}=5.46, p<0.05\right)$ during training, suggesting that subjects exhibited within-session extinction; however, we found no significant effect of genotype on within-session extinction (Figure 3c). Thus, by our measures, constitutive, global knockout of CCKBR does not affect cued fear acquisition, fear expression, extinction retention, or within-session extinction.

\section{Knockout of CCKBR Blunts Cnr1 Antagonist-Mediated Increases in Freezing Across Cued Fear Expression and Extinction Retention Test Days}

To address our central hypothesis of a potential Cnr1CCKBR interaction, we next injected CCKBR knockout and wild-type littermates with SR141716A before cued fear 
a

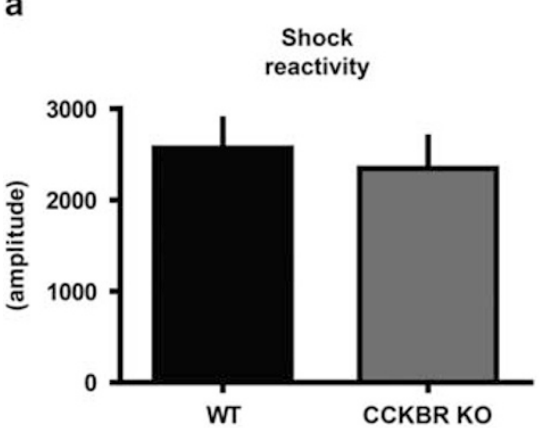

C

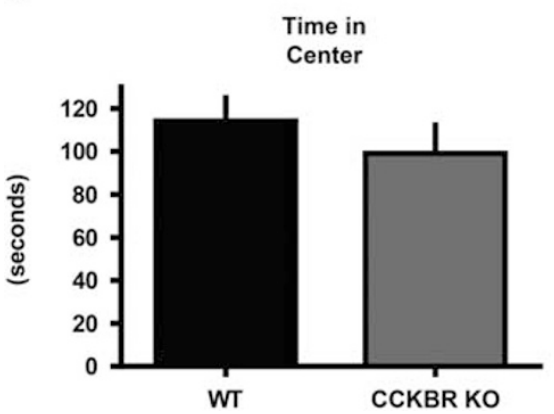

b

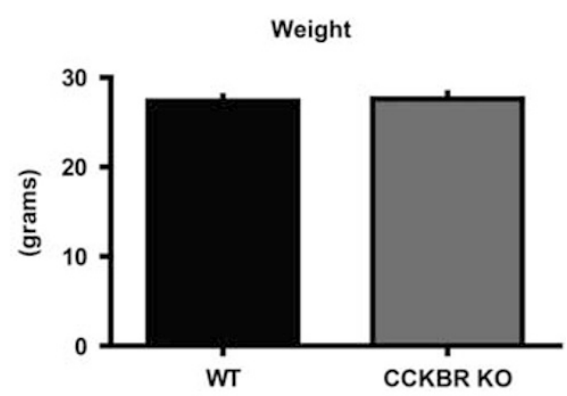

d
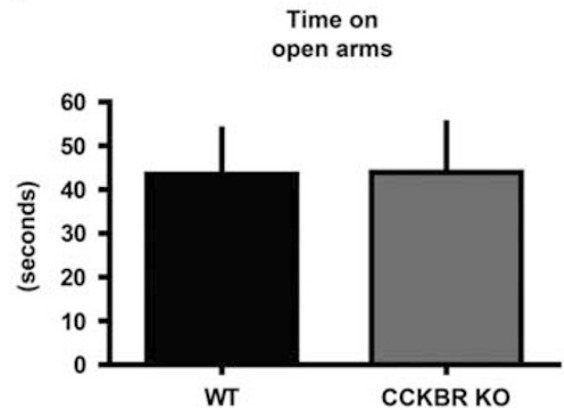

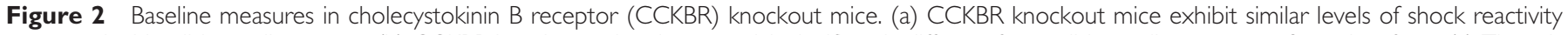

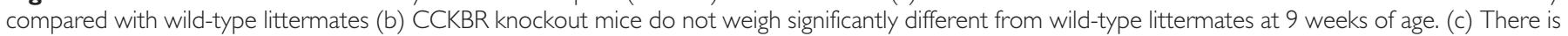

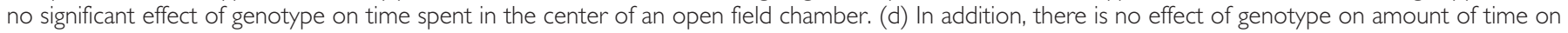
the open arms of an elevated plus maze.

expression/extinction training. We previously demonstrated that acute administration of SR141716A increased freezing behavior during cued fear expression/extinction training in C57BL/6J mice. Here, we examined this effect in CCKBR knockout mice, dissociating cued fear expression and extinction retention from within-session extinction to explicitly examine the effect of SR141716A on each phase of learning. Again, we observed no significant effect of genotype on freezing behavior during cued fear acquisition (Figure 4a). As expected, SR141716A-administered wildtype subjects froze significantly more across cued fear expression and extinction retention test days compared with vehicle-administered wild-type subjects (Figure 4b). In contrast, SR141716A-treated CCKBR knockout mice exhibited virtually identical levels of freezing behavior compared with vehicle-administered CCKBR knockout mice (Figure 4c) across cued fear expression and extinction retention test days (repeated-measures ANOVA, genotype $\times$ drug interaction, $F_{1,55}=2.87, p<0.05$, one-tailed). One-tailed statistical analysis was performed as we predicted a priori a directional effect of Cnr1-CCKBR interaction. We did not observe a significant interaction between genotype $\times$ drug $\times$ test day. Post hoc tests reveal a significant difference between wild-type subjects administered vehicle $v s$ wild-type littermates administered SR141716A $\left(\mathrm{F}_{1,31}=4.82, p<0.05\right)$ across cued fear expression and extinction retention test days. Statistical analysis revealed a significant effect of CS bin on freezing $\left(\mathrm{F}_{1.56,85.63}=31.49, p<0.05\right)$ during training, suggesting that subjects exhibited within-session extinction; however, we found no significant main effect of genotype or drug, nor an interaction effect, on within-session extinction (Figure $4 \mathrm{~d}$ ).
These results suggest that CCKBR is downstream of Cnr1 activation during cued fear expression and extinction retention.

\section{Cnr1-Positive Fibers form Perisomatic Baskets Around CCKBR-Positive Cell Bodies in the BLA}

Next, we performed immunohistochemistry experiments to determine the cellular localization of Cnr1 and CCKBR in the BLA. The amygdala processes emotionally relevant stimuli via the interactions of neurotransmitters (Bowers et al, 2012) and is enriched in Cnr1, CCK, and CCKBR (Larsson and Rehfeld, 1979; Herkenham et al, 1990; Lein et al, 2007). Prior studies have demonstrated a high degree of colocalization between $\mathrm{Cnr} 1$ and CCK mRNA and protein in the BLA (McDonald and Mascagni, 2001; Chhatwal et al, 2009). Furthermore, perisomatic diacylglyerol lipase (DGL $\alpha$, which synthesizes 2-AG, one of the major endocannabinoids) clusters selectively appose interneuron terminals expressing Cnr1, CCK, and monoacylglycerol lipase (MGL, degrades 2-AG) (Yoshida et al, 2011). We first performed single-labeling experiments to separately determine immunoreactivity of Cnr1 and CCKBR in the amygdala (for information on development and testing of these antibodies see Morisset et al, 2003; Rooman et al, 2001; Tsou et al, 1998). Cnr1 was detected in the lateral and BLA amygdala, but only minimally within the central amygdala (CeA) (Figure 5a). CCKBR was detected in all three amygdala subnuclei (LA, BLA, and CeA) (Figure 5b). At higher magnifications, Cnrl immunoreactivity appeared primarily on fibers in the BLA (Figure 5c). In contrast, CCKBR localized specifically to cell bodies in the amygdala 
a

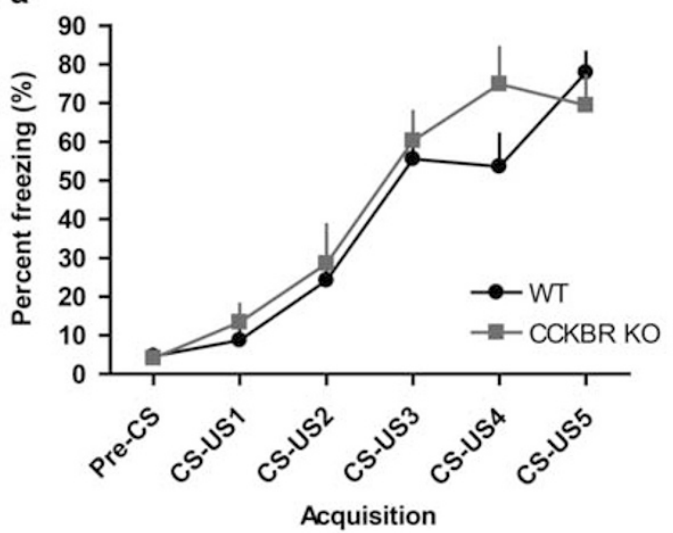

b

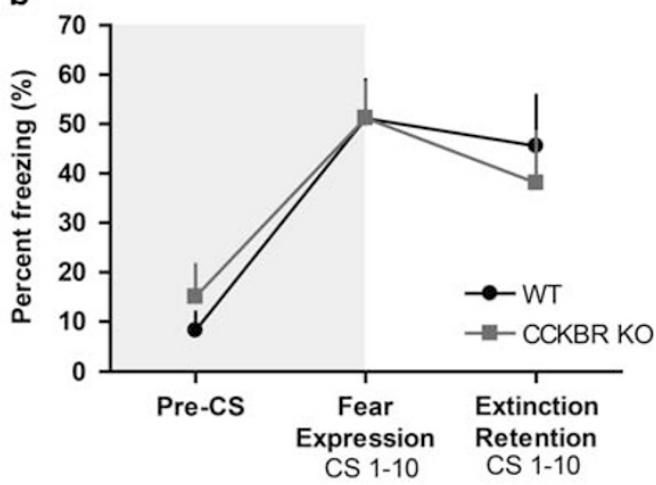

C
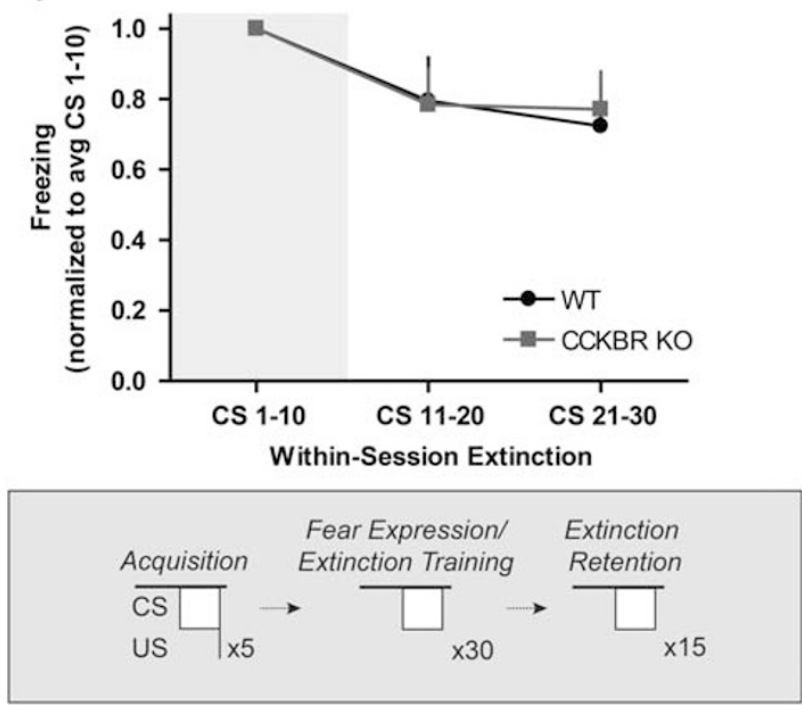

Figure 3 CCKBR knockout mice exhibit normal cued fear learning. (a) CCKBR knockout and wild-type littermates do not exhibit significantly different freezing behavior during cued fear acquisition, (b) fear expression, or extinction retention. (c) There is no effect of genotype on within-session extinction.

(Figure 5d). To better understand how Cnr1 and CCKBR might functionally interact, we performed serial, doublelabeling immunohistochemistry (as antibodies against Cnrl and CCKBR share the same host). Incubations were performed in the following order: rabbit anti-CCKBR, goat anti-rabbit Alexa-Fluor 488, rabbit anti-Cnr1, goat anti- rabbit Alexa-Fluor 568. High-magnification photomicrographs of the BLA showed Cnr1-positive fibers form perisomatic baskets around CCKBR-positive cell bodies (Figure 5e and $\mathrm{f}$ ). We detected ectopic Cnr1 immunoreactivity on cell bodies. This was likely the result of goat anti-rabbit Alexa-Fluor 568 secondary reacting with unbound rabbit anti-CCKBR antibody, rather than true detection of Cnrl on cell bodies. The results of these immunohistochemistry experiments support our behavioral findings, in that CCKBR appears to be downstream of Cnr1 modulation through perisomatic input of Cnrl-containing synapses onto CCKBR cell bodies.

\section{CCKBR Colocalizes with Markers for Excitatory and Inhibitory Neurons in the BLA}

To generate a clearer picture of how inhibition of CCK might influence BLA neurotransmission, we performed double labeling experiments with antibodies against CCKBR and markers of excitatory and inhibitory neurons. We found that CCKBR colocalizes with calbindin and calretinin (Figure 6a$\left.a^{\prime \prime}, c-c^{\prime \prime}\right)$. Calbindin and calretinin are calcium-binding proteins expressed in the two major non-overlapping populations of interneurons in the BLA. Further, CCKBR colocalizes with parvalbumin (Figure $6 \mathrm{~b}-\mathrm{b}^{\prime \prime}$ ). Parvalbumin is a calcium-binding protein that is co-expressed in a proportion of calbindin interneurons. In addition, CCKBR colocalizes with calcium/calmodulin-dependent protein kinase II alpha (CaMKII $\alpha$ ), which is expressed almost exclusively in excitatory cells in the BLA (Figure $6 \mathrm{~d}-\mathrm{d}^{\prime \prime}$ ).

\section{DISCUSSION}

The present study demonstrates the following: (1) systemic SR141716A, a Cnr1 antagonist, increases cued fear expression in C57BL/6J mice; (2) systemic URB597, an FAAH inhibitor-which increases activation of Cnrl, decreases cued fear expression in C57BL/6J mice; (3) global CCKBR knockout has no effect on weight, shock reactivity, fear- or anxiety-like behavior; (4) SR141716A increases freezing behavior across cued fear expression and extinction retention test days in wild-type littermates, as expected, but has no effect on freezing behavior in CCKBR knockouts; (5) Cnr1-positive fibers form perisomatic baskets around CCKBR-positive cell bodies in the BLA; and (6) CCKBR colocalizes with markers of both excitatory and inhibitory neurons in the BLA.

As it has been demonstrated previously, we find that $\mathrm{Cnr} 1$ is critical for inhibition of cued fear (Marsicano et al, 2002; Riebe et al, 2012). In this study, we show that manipulation of the cannabinoid system alters cued fear expression. These results are consistent with a prior study testing the effect of the Cnr1 antagonist AM251 on delay fear conditioning (Reich et al, 2008). Other studies, however, demonstrate that knockout or antagonism of the Cnr1 receptor has no effect of fear expression, but persistently blocks within-session extinction (Marsicano et al, 2002).

In addition, we find that enhancement of anandamide tone via administration of URB597, an FAAH inhibitor, decreases cued fear expression. This is consistent with reports demonstrating that URB597 promotes extinction of 
conditioned aversion (Manwell et al, 2009). Our laboratory has previously shown that AM404, an inhibitor of anandamide uptake, attenuates fear-potentiated startle (Chhatwal et al, 2005). Furthermore, AM3506, a different
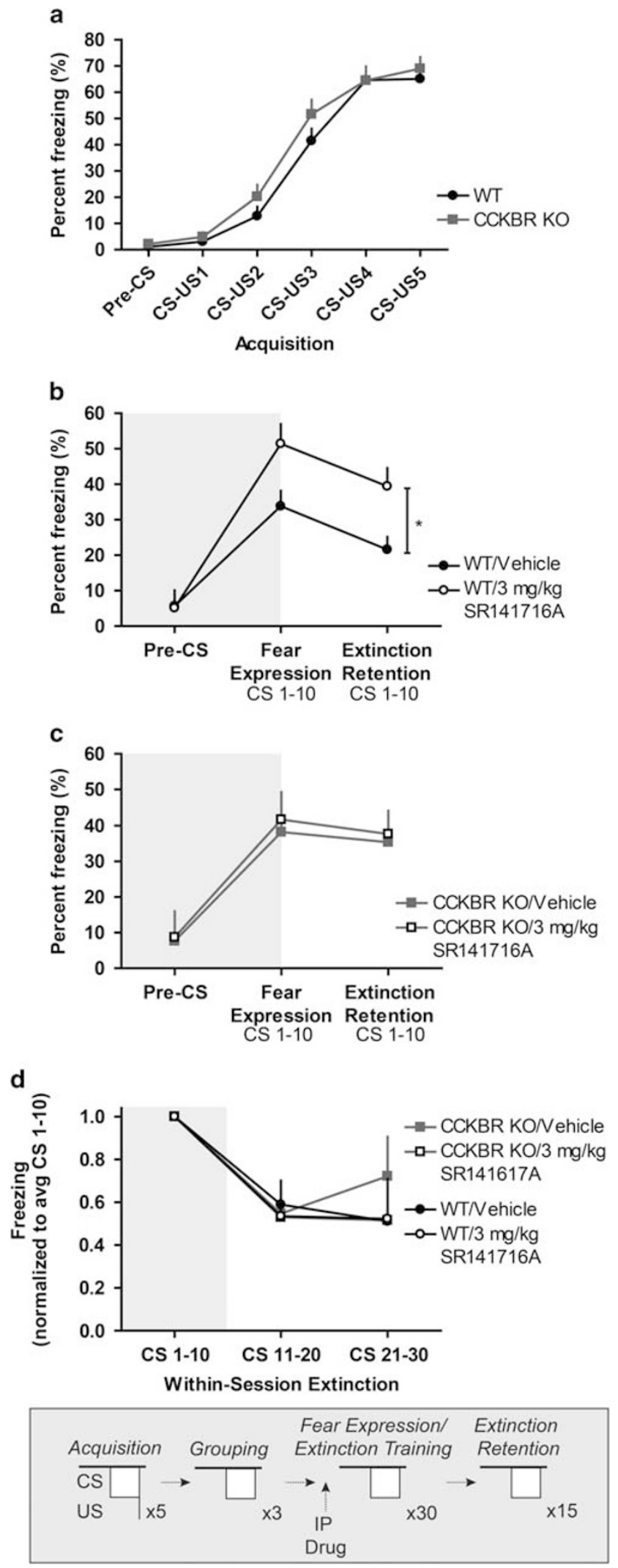

FAAH inhibitor, decreases freezing behavior during a retrieval test when administered before extinction (Gunduz-Cinar et al, 2013). Human studies demonstrate that carriers of a low-expressing FAAH variant (385A allele; rs 324420) exhibit decreased amygdala reactivity and faster habituation of amygdala reactivity in response to threat. In addition, these carriers have lower scores on the personality trait of stress-reactivity (Hariri et al, 2009; Gunduz-Cinar et al, 2013). Importantly, neither SR141716A nor URB597at the doses tested-has effects on locomotion (Compton et al, 1996; Tzavara et al, 2003) (Supplementary Figure S4). Altogether, the results of these experiments are in line with the literature, suggesting that the cannabinoid system has a critical role in the expression of cued fear.

Separately, we observe no effect of global CCKBR knockout on baseline measures of weight, shock reactivity, locomotion, or anxiety-like behavior in mice. We performed open-field and elevated plus maze tests to assess any potential confounds of an anxiety-like phenotype on fear behavior and to further clarify conflicting prior evidence. Previous studies show that CCK can increase anxiety, eliciting panic attacks in humans (de Montigny, 1989; Bradwejn et al, 1990, 1991). However, evidence for the role of CCKBR in rodent anxiety-like behavior is mixed. Although some studies show an anxiolytic effect of CCKBR antagonists and CCKBR knockout (Matto et al, 1997, Revel et al, 1998, Tsutsumi et al, 1999, Abramov et al, 2008), others report null results (Johnson and Rodgers, 1996, Griebel et al, 1997). Still, others report that CCKBR antagonists only have anxiolytic effects when coadministered with CCK (Hernandez-Gomez et al, 2002). The mixed conclusions of the literature suggest that CCKBR likely has a role in anxiety-like behavior, but that the CCK system might be particularly sensitive to environmental conditions, prior stress, and/or specific testing parameters.

We find no significant effect of global CCKBR knockout on a number of measures of cued fear. Although we proposed that CCKBR knockout mice would show enhanced extinction, our results are consistent with our central hypothesis. If we predict that CCKBR activation during cued fear expression/extinction is minimal, due to Cnr1mediated inhibition of CCK, global CCKBR knockout should not exert an effect on cued fear expression/ extinction. Like the anxiety literature, evidence for the role of CCKBR in cued freezing and fear-potentiated startle is somewhat mixed. Work from our laboratory demonstrates that administration of a CCKBR antagonist before extinction training has no effect on fear-potentiated startle in rats $48 \mathrm{~h}$ later (Chhatwal et al, 2009). Raud et al (2005) find no

Figure 4 Knockout of CCKBR blunts Cnrl antagonist-mediated increase in freezing across cued fear expression and extinction retention test days. (a) CCKBR knockout and wild-type littermates do not exhibit significantly different freezing behavior during cued fear acquisition. (b) IP administration of $3 \mathrm{mg} / \mathrm{kg}$ SRI4I7I6A increases freezing behavior across cued fear expression and extinction retention test days in wild-type mice. (c) Vehicleand SRI4I7I6A-treated CCKBR knockout mice do not exhibit significantly different freezing behavior across cued fear expression and extinction retention test days. (d) All groups show similar rates of within-session extinction. Average freezing in response to a three-CS 'grouping' test was used to organize subjects into separate groups (grouping data not shown). Asterisk denotes $p<0.05$. 

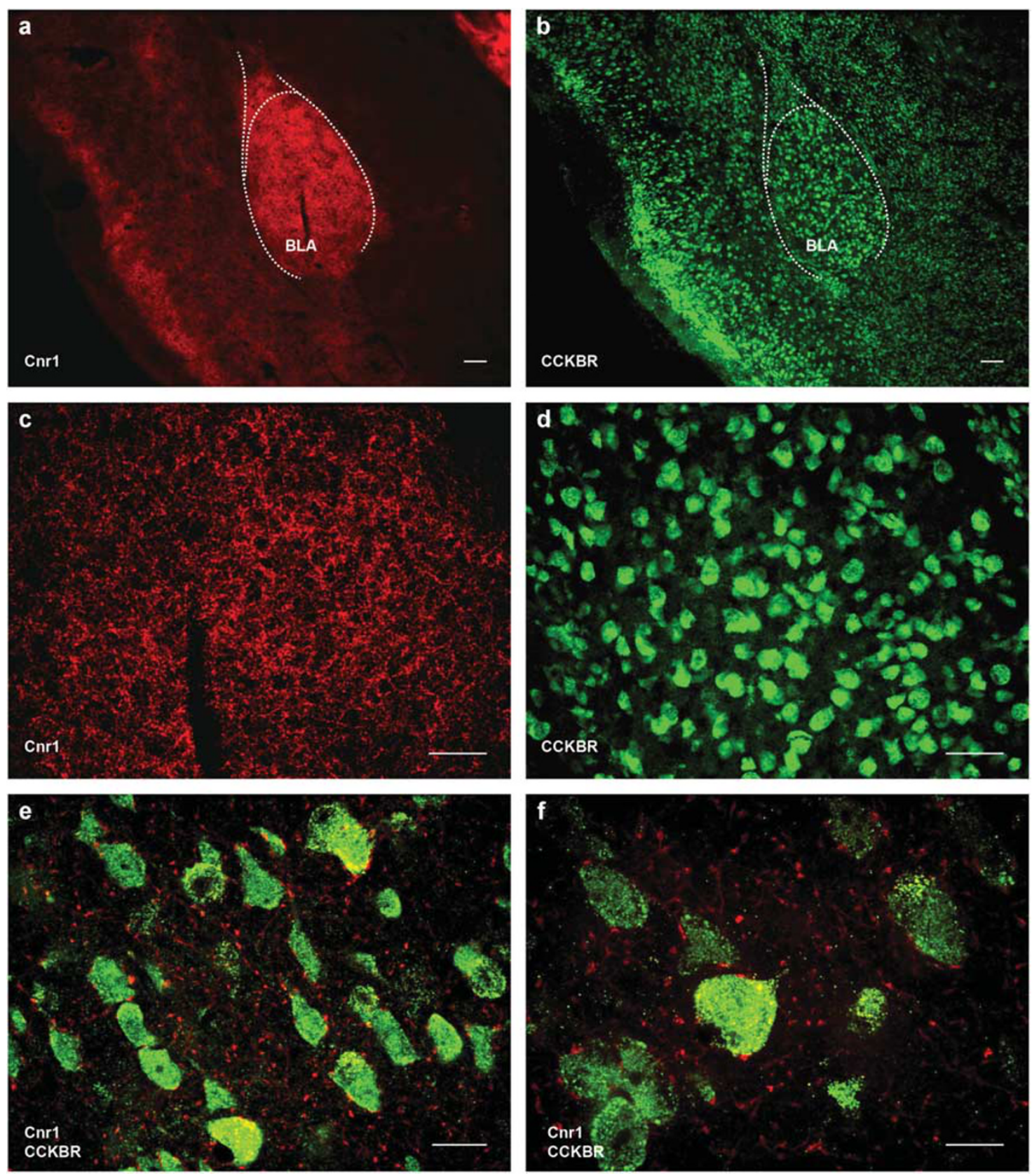

Figure $5 \mathrm{Cnrl}$-positive fibers form perisomatic baskets around CCKBR-positive cell bodies in the BLA. (a) Photomicrograph showing immunoreactivity of $\mathrm{Cnrl}$ in the amygdala. Cnrl localizes to lateral (LA), basolateral (BLA), but not central (CeA) amygdala ( $\times 4$ magnification, I00 $\mu$ m scale bar). (b) Photomicrograph showing immunoreactivity of CCKBR in the amygdala. CCKBR localizes to LA, BLA, and CeA ( $\times 4$ magnification, I00 $\mu$ m scale bar). (c) Cnrl localizes to fibers in the BLA ( $\times 20$ magnification, $50 \mu \mathrm{m}$ scale bar). (d) CCKBR localizes to cell bodies in the BLA ( $\times 20$ magnification, $50 \mu \mathrm{m}$ scale bar). (e and f) Photomicrograph showing immunoreactivity of $\mathrm{Cnrl}$ (red) and CCKBR (green) in the BLA ( $\times 63$ and $\times 100$ magnification with I5 and $10 \mu \mathrm{m}$ scale bars, respectively).

differences in cued fear between wild-type and CCKBR knockout littermate females, although extensive testing of extinction was not conducted. However, pentagastrin, a CCKBR agonist, enhances acoustic startle and blocks extinction of fear-potentiated startle in rats (Frankland et al, 1996; Chhatwal et al, 2009). In addition, Josselyn et al (1995) find that administration of a CCKBR antagonist before startle testing (after cued fear acquisition) attenuates fear-potentiated startle. The behavioral differences observed across studies might be attributed to species- specific organization of the CCK system (Sekiguchi and Moroji, 1986; Dietl and Palacios, 1989; Kuwahara et al, 1993). In addition, a caveat of our study is the use of a constitutive knockout line with a 129S1 strain background. Compared to C57BL/6 mice, the 129S1 strain shows delayed extinction of conditioned fear (Hefner et al, 2008; Camp et al, 2009). Further, future studies should test transgenic strains with precise spatial and temporal control of CCKBR expression to avoid potential genetic compensation issues. 

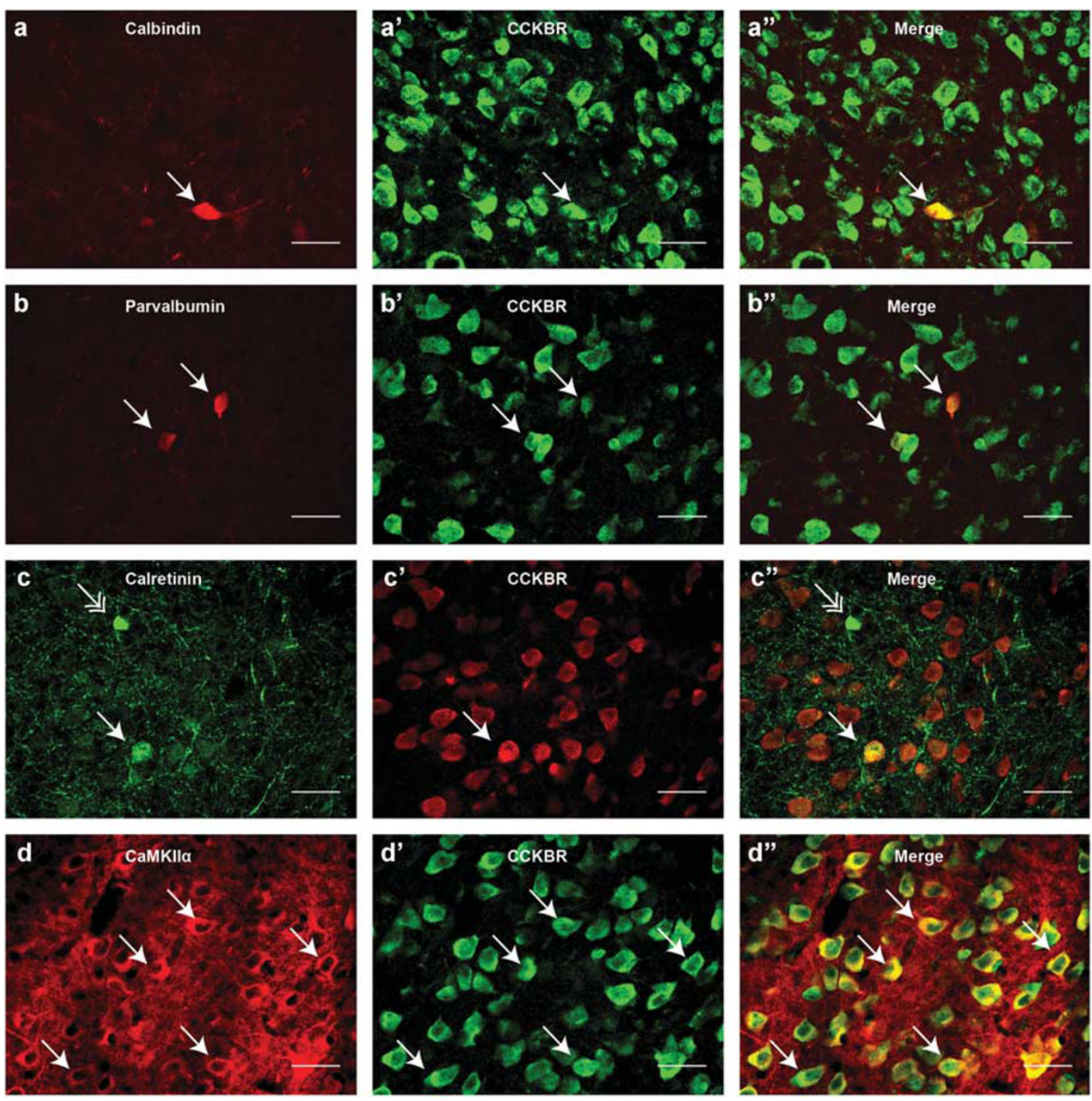

Figure 6 CCKBR colocalizes with markers of excitatory and inhibitory neurons in the BLA. (a-a $\left.a^{\prime \prime}\right)$ Photomicrographs showing colocalization of calbindin ( $a$, red) and CCKBR $\left(a^{\prime}\right.$, green) in the BLA $\left(a^{\prime \prime}\right.$, merged). (b-b") Photomicrographs showing colocalization of parvalbumin (b, red) and CCKBR ( $b^{\prime}$, green) in the BLA ( $b^{\prime \prime}$, merged). ( $\left.c-c^{\prime \prime}\right)$ Photomicrographs showing colocalization of calretinin ( $c$, green) and CCKBR ( $c^{\prime}$, red) in the BLA ( $c^{\prime \prime}$, merged). $\left(d-d^{\prime \prime}\right)$ Photomicrograph showing colocalization of calcium/calmodulin-dependent protein kinase II alpha (CaMKIl $\left.\alpha\right)(d, r e d)$ with CCKBR ( $d^{\prime}$, green) in the BLA ( $d^{\prime \prime}$, merged) ( $\times 40$ magnification, $30 \mu \mathrm{m}$ scale bar).

Importantly, we find that Cnr1 antagonist treatment, which increases freezing across cued fear expression and extinction retention test days in wild-type subjects, has no effect on freezing behavior in CCKBR knockout littermates. These results suggest that CCKBR is downstream of Cnr1 activation primarily during cued fear expression. We propose that administration of a Cnrl antagonist prevents Cnr1-mediated suppression of CCK release and subsequent activation of CCKBR, increasing freezing during cued fear expression. Knockout of CCKBR reverses this Cnr1 antagonist-mediated increase in freezing behavior. Prior data from our laboratory demonstrates that $\mathrm{Cnrl}$ and CCKBR, while using pharmacological probes, interact to mediate extinction of fear-potentiated startle in rats (Chhatwal et al, 2009). Interestingly, the endocannabinoids and cholecystokinin are thought to interact to modulate appetite, via central and/or peripheral mechanisms (Orio et al, 2011; Alen et al, 2013). Slice physiology studies propose an alternative Cnr1-CCK interaction in the hippocampus. According to the 'Cnr1 receptor hypothesis', CCK activation of CCKBR initiates endocannabinoid synthesis, activating pre-synaptic Cnrl on CCK-containing interneurons to inhibit GABA transmission. Separately, CCK strongly depolarizes parvalbumin interneurons via CCKBR, increasing firing frequency of inhibitory currents (Foldy et al, 2007; Karson et al, 2008; Lee and Soltesz, 2011; Lee et al, 2011). Although our results suggest that CCKBR is downstream of Cnr1, cell-type specific behavioral studies will better clarify the differences in our respective models of a Cnr1-CCKBR interaction.

Consistently, our results suggest that Cnrl and a Cnr1CCKBR interaction is critical to cued fear expression, rather 
than within-session extinction, as we originally predicted. As mentioned, this effect is in contrast to prior data suggesting that $\mathrm{Cnr} 1$ primarily contributes to within-session extinction (Marsicano et al, 2002; Plendl and Wotjak, 2010). However, these studies used individually-housed subjects conditioned with one tone-shock pairing. Individual housing has been shown to have significant effects on fear- and anxiety-like behavior (Voikar et al, 2005). In contrast, we fear conditioned group-housed subjects with at least five tone-shocks. From a clinical perspective, this suggests that pharmacological interventions aimed at the CCK and/or cannabinoid systems may differentially affect within- or between-session extinction based on the level of prior trauma and the type of exposure protocol. Likewise, the effect of SR141716A on C57BL/6J vs wild-type CCKBR freezing behavior on extinction retention might be explained by training and strain differences (Figures $1 a^{\prime}$ and 4b). Future studies should address whether Cnrl and CCKBR interact to mediate within-session extinction.

Our behavioral results are supported by immunofluorescence evidence, showing that Cnr1-positive fibers form perisomatic baskets around CCKBR-positive cell bodies in the BLA. Although our behavioral experiments were performed systemically, we chose to perform immunofluorescence on the BLA. Ample evidence implicates this area in cue-dependent fear learning (Davis, 1992; Maren and Fanselow, 1996; Fanselow and LeDoux, 1999; LeDoux, 2000). Recent evidence, however, suggests that activity in the medial prefrontal cortex (mPFC) is critical for cued fear learning, in addition to the amygdala (Quirk et al, 1995, 2003). As anatomical evidence demonstrates that CCK, CCKBR and Cnr1 localize to prefrontal cortex (Larsson and Rehfeld, 1979; Zarbin et al, 1983; Herkenham et al, 1990) and behavioral studies implicate prefrontal Cnrl in fear (Laviolette and Grace, 2006; Lin et al, 2008, 2009; Ganon-Elazar and Akirav, 2013; Kuhnert et al, 2013), similar immunofluorescence experiments should be performed in mPFC. In addition, site-specific behavioral experiments should be conducted in follow-up studies to determine whether the observed Cnr1CCKBR interaction occurs in BLA.

To determine how inhibition of CCK might contribute to cued fear expression, we examined CCKBR immunoreactivity in the amygdala. We initially hypothesized that CCKBR would localize primarily to excitatory projection neurons, as prior evidence suggests that CCK is an axiogenic/panicogenic peptide (de Montigny, 1989). Furthermore, MGL and Cnrl intensively accumulate at inhibitory synapses targeting pyramidal neurons in the BLA (Yoshida et al, 2011). We find that CCKBR colocalizes with markers of excitatory projection neurons, as well as local inhibitory neurons in the BLA. This suggests that CCK, as well as putative Cnrl-mediated inhibition of CCK, may exert a complex, computational effect on amygdaladependent fear circuits. To more quantitatively asses how widely CCKBR is distributed throughout inhibitory and excitatory networks, stereological analysis will need to be performed. Our immunohistochemistry results are consistent with the physiology literature, which shows that CCK excites projection neurons and interneurons (Chung and Moore, 2007, 2009b; Meis et al, 2007). CCK directly initiates a mixed cationic, depolarizing current in projection neurons (Meis et al, 2007). These CCK-activated currents,

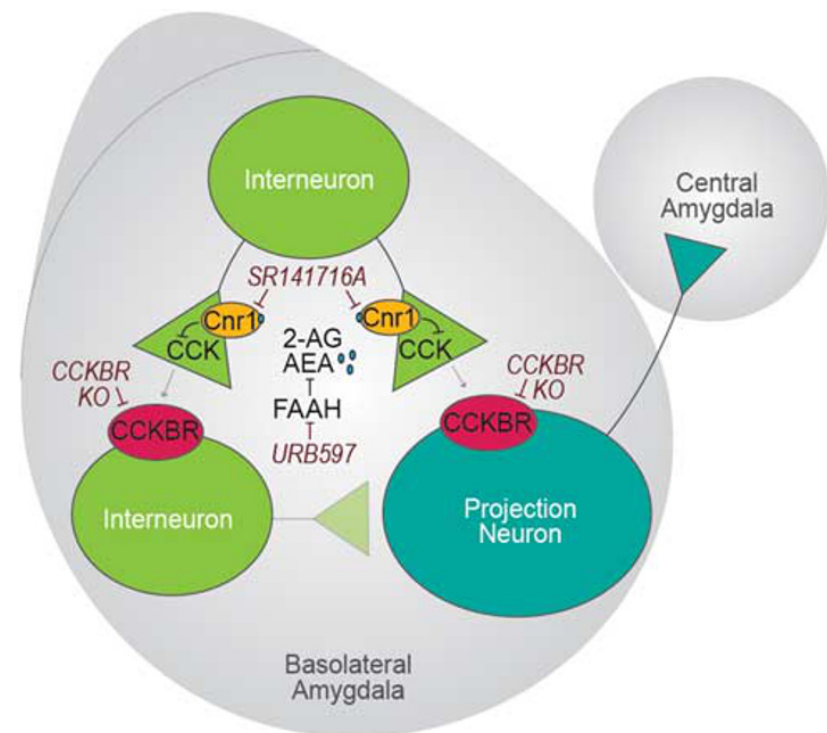

Figure 7 Schematic of putative Cnrl-CCKBR interaction during cued fear expression: future directions. We hypothesize that activation of pre-synaptic $\mathrm{Cnrl}$ during cued fear expression decreases probability of release via regulation of ion channels. CCK transmission is inhibited, preventing activation of CCKBR on excitatory and inhibitory neurons in the BLA. As a result, depolarizing TRP (transient receptor potential) channel currents on projection neurons are not activated (Meis et al, 2007). Similarly, CCKBR-induced excitation of inhibitory neurons is unable to coordinate projection neuron firing. We speculate that $\mathrm{Cnrl-CCKBR-mediated} \mathrm{weakening} \mathrm{of} \mathrm{projection} \mathrm{neuron} \mathrm{excitation} \mathrm{and}$ potential disruption of BLA oscillations could contribute to decreased signaling to the CeA, thus dampening fear behavior during cued fear expression. Together these effects may also enhance extinction of fear via Cnrl activation when the CS is not reinforced. In contrast, when $\mathrm{Cnrl}$ activation is inhibited, CCKBR activation leads to enhanced projection neuron firing concomitant with potentially increased interneuronal coordination of firing patterns, thus maintaining the fear response to the CS. Although our experiments suggest that $\mathrm{Cnrl}$ and CCKBR interact to mediate cued fear expression, future experiments will need to address the hypotheses put forth in this schematic.

via CCKBR, seem to be mediated by TRP (transient receptor potential) channels, specifically TRPC1/4/5 (Meis et al, 2007). CCK, via activation of interneurons-in particular, parvalbumin interneurons, could modulate BLA oscillations. BLA parvalbumin interneurons can innervate $\sim 150$ projection neurons, a property which is thought to be critical for coordinating projection neuron activity and facilitating oscillations (Muller et al, 2005; Woodruff and Sah, 2007; Ryan et al, 2012). These parvalbumin interneurons form perisomatic baskets around projections of neuron cell bodies, strongly inhibiting excitatory output (McDonald et al, 2005). Interestingly, CCK can elicit rhythmic, compound IPSPs in rat BLA projection neurons (Chung and Moore, 2009a) and activation of Cnr1 has been shown to inhibit hippocampal network oscillations (Hajos et al, 2000; Robbe et al, 2006). In this way, Cnrl-mediated inhibition of CCK could disrupt or dampen synchronous output to the CeA from BLA projection neurons, decreasing activation of the HPA axis, PAG, and other regions critical for mediating fear behavior output.

Taken together, these findings suggest that Cnrl affects cued fear expression, in part, by decreasing activation of CCKBR, potentially via inhibition of the anxiogenic neuropeptide CCK (Figure 7). Human studies demonstrate that 
individuals with PTSD have greater CNS Cnr1 availability compared with controls. Elevated Cnrl availability is thought to be driven by increased receptor upregulation caused by low anandamide levels (Neumeister et al, 2013). Our data suggest that decreased anandamide levels in individuals with PTSD could drive excess/aberrant CCK signaling. In fact, a number of studies support a link between the CCK system and panic, which may share a similar neurobiological mechanism with post-traumatic flashbacks (Mellman and Davis, 1985; de Montigny, 1989; Bradwejn et al, 1990, 1991; Kellner et al, 2000).

How, exactly, CCK promotes fear and anxiety is still unclear, but some studies suggest that CCK may act, in part, through the corticotropin-releasing factor (CRF) system (Biro et al, 1993; Kellner et al, 1997; Shlik et al, 1997). Our results suggest that BLA CCK likely activates a complex network of excitatory and inhibitory circuitry, which is modulated via Cnrl regulation. Although more work is needed to clarify the functional relationship between CCK and Cnrl, the results of this study suggest that dysfunction in a putative Cnr1-CCKBR interaction might be critical to understand the etiology, and ultimately treatment, of fearrelated disorders. Indeed, a synthetic cannabinoid has recently been shown to reduce treatment-resistant nightmares in a majority of PTSD patients (Fraser, 2009). These studies show promise that the use of CCKBR antagonists alone, or in combination with cannabinoid-targeted treatments, may prove to be ameliorative with exposure-based psychotherapy.

\section{FUNDING AND DISCLOSURE}

Support was provided by NIH (T32-GM08605, 1F31MH097397, and R01MH096764), the Burroughs Wellcome Fund, and by an NIH/NCRR base grant (P51RR000165) to Yerkes National Primate Research Center. The authors declare no conflict of interest.

\section{ACKNOWLEDGEMENTS}

We thank Dr Bradley Alger and Dr Ken Mackie for their generous contributions of antibodies. We are grateful to Dr Donald Rainnie and Dr Joanna Dabrowska for confocal microscopy assistance. Additionally, we are grateful to $\mathrm{Dr}$ Shannon Gourley, Dr Brian Dias, Dr Raül Andero, Dr David Ehrlich and Dr Stephanie Maddox for constructive comments.

\section{REFERENCES}

Abramov U, Raud S, Innos J, Lasner H, Kurrikoff K, Turna T et al (2008). Different housing conditions alter the behavioural phenotype of CCK(2) receptor-deficient mice. Behav Brain Res 193: pp 108-116.

Alen F, Ramirez-Lopez MT, Gomez de Heras R, Rodriguez de Fonseca F, Orio L (2013). Cannabinoid receptors and cholecystokinin in feeding inhibition. Vitam Horm 92: pp 165-196.

Areda T, Raud S, Philips MA, Innos J, Matsui T, Koks S et al (2006). Cat odour exposure decreases exploratory activity and alters neuropeptide gene expression in CCK(2) receptor deficient mice, but not in their wild-type littermates. Behav Brain Res 169: pp 212-219.
Azad SC, Eder M, Marsicano G, Lutz B, Zieglgansberger W, Rammes G (2003). Activation of the cannabinoid receptor type 1 decreases glutamatergic and GABAergic synaptic transmission in the lateral amygdala of the mouse. Learn Mem 10: pp 116-128.

Azad SC, Monory K, Marsicano G, Cravatt BF, Lutz B, Zieglgansberger W et al (2004). Circuitry for associative plasticity in the amygdala involves endocannabinoid signaling. J Neurosci 24: pp 9953-9961.

Beinfeld MC, Connolly K (2001). Activation of CB1 cannabinoid receptors in rat hippocampal slices inhibits potassium-evoked cholecystokinin release, a possible mechanism contributing to the spatial memory defects produced by cannabinoids. Neurosci Lett 301: pp 69-71.

Biro E, Sarnyai Z, Penke B, Szabo G, Telegdy G (1993). Role of endogenous corticotropin-releasing factor in mediation of neuroendocrine and behavioral responses to cholecystokinin octapeptide sulfate ester in rats. Neuroendocrinology 57: pp 340-345.

Bowers ME, Choi DC, Ressler KJ (2012). Neuropeptide regulation of fear and anxiety: Implications of cholecystokinin, endogenous opioids, and neuropeptide Y. Physiol Behav 107: pp 699-710.

Bradwejn J, Koszycki D, Meterissian G (1990). Cholecystokinintetrapeptide induces panic attacks in patients with panic disorder. Can J Psychiatry 35: pp 83-85.

Bradwejn J, Koszycki D, Shriqui C (1991). Enhanced sensitivity to cholecystokinin tetrapeptide in panic disorder. Clinical and behavioral findings. Arch Gen Psychiatry 48: pp 603-610.

Camp M, Norcross M, Whittle N, Feyder M, D'Hanis W, YilmazerHanke D et al (2009). Impaired Pavlovian fear extinction is a common phenotype across genetic lineages of the 129 inbred mouse strain. Genes Brain Behav 8: pp 744-752.

Chhatwal JP, Davis M, Maguschak KA, Ressler KJ (2005). Enhancing cannabinoid neurotransmission augments the extinction of conditioned fear. Neuropsychopharmacology 30: pp 516-524.

Chhatwal JP, Gutman AR, Maguschak KA, Bowser ME, Yang Y, Davis $M$ et al (2009). Functional interactions between endocannabinoid and CCK neurotransmitter systems may be critical for extinction learning. Neuropsychopharmacology 34: pp 509-521.

Chung L, Moore SD (2007). Cholecystokinin enhances GABAergic inhibitory transmission in basolateral amygdala. Neuropeptides 41: pp 453-463.

Chung L, Moore SD (2009a). Neuropeptides modulate compound postsynaptic potentials in basolateral amygdala. Neuroscience 164: pp 1389-1397.

Chung L, Moore SD (2009b). Cholecystokinin excites interneurons in rat basolateral amygdala. J Neurophysiol 102: pp 272-284.

Compton DR, Aceto MD, Lowe J, Martin BR (1996). In vivo characterization of a specific cannabinoid receptor antagonist (SR141716A): inhibition of delta 9-tetrahydrocannabinol-induced responses and apparent agonist activity. J Pharmacol Exp Ther 277: pp 586-594.

Cravatt BF, Giang DK, Mayfield SP, Boger DL, Lerner RA, Gilula NB (1996). Molecular characterization of an enzyme that degrades neuromodulatory fatty-acid amides. Nature 384: pp 83-87.

Davis M (1992). The role of the amygdala in fear and anxiety. Annu Rev Neurosci 15: pp 353-375.

de Montigny C (1989). Cholecystokinin tetrapeptide induces panic-like attacks in healthy volunteers. Preliminary findings. Arch Gen Psychiatry 46: pp 511-517.

Dietl MM, Palacios JM (1989). The distribution of cholecystokinin receptors in the vertebrate brain: species differences studied by receptor autoradiography. J Chem Neuroanat 2: pp 149-161.

Fanselow MS, LeDoux JE (1999). Why we think plasticity underlying Pavlovian fear conditioning occurs in the basolateral amygdala. Neuron 23: pp 229-232.

Foldy C, Lee SY, Szabadics J, Neu A, Soltesz I (2007). Cell typespecific gating of perisomatic inhibition by cholecystokinin. Nat Neurosci 10: pp 1128-1130. 
Frankland PW, Josselyn SA, Bradwejn J, Vaccarino FJ, Yeomans JS (1996). Intracerebroventricular infusion of the CCKB receptor agonist pentagastrin potentiates acoustic startle. Brain Res 733: pp 129-132.

Frankland PW, Josselyn SA, Bradwejn J, Vaccarino FJ, Yeomans JS (1997). Activation of amygdala cholecystokininB receptors potentiates the acoustic startle response in the rat. $J$ Neurosci 17: pp 1838-1847.

Fraser GA (2009). The use of a synthetic cannabinoid in the management of treatment-resistant nightmares in posttraumatic stress disorder (PTSD). CNS Neurosci Ther 15: pp 84-88.

Ganon-Elazar E, Akirav I (2013). Cannabinoids and traumatic stress modulation of contextual fear extinction and GR expression in the amygdala-hippocampal-prefrontal circuit. Psychoneuroendocrinology 38: pp 1675-1687.

Griebel G, Perrault G, Sanger DJ (1997). CCK receptor antagonists in animal models of anxiety: comparison between exploration tests, conflict procedures and a model based on defensive behaviours. Behav Pharmacol 8: pp 549-560.

Gunduz-Cinar O, MacPherson KP, Cinar R, Gamble-George J, Sugden K, Williams B et al (2013). Convergent translational evidence of a role for anandamide in amygdala-mediated fear extinction, threat processing and stress-reactivity. Mol Psychiatry 18: pp 813-823.

Hajos N, Katona I, Naiem SS, MacKie K, Ledent C, Mody I et al (2000). Cannabinoids inhibit hippocampal GABAergic transmission and network oscillations. Eur J Neurosci 12: pp 3239-3249.

Hariri AR, Gorka A, Hyde LW, Kimak M, Halder I, Ducci F et al (2009). Divergent effects of genetic variation in endocannabinoid signaling on human threat- and reward-related brain function. Biol Psychiatry 66: pp 9-16.

Hefner K, Whittle N, Juhasz J, Norcross M, Karlsson RM, Saksida LM et al (2008). Impaired fear extinction learning and corticoamygdala circuit abnormalities in a common genetic mouse strain. J Neurosci 28: pp 8074-8085.

Herkenham M, Lynn AB, Little MD, Johnson MR, Melvin LS, de Costa BR et al (1990). Cannabinoid receptor localization in brain. Proc Natl Acad Sci USA 87: pp. 1932-1936.

Hernandez-Gomez AM, Aguilar-Roblero R, Perez de la Mora M (2002). Role of cholecystokinin-A and cholecystokinin-B receptors in anxiety. Amino Acids 23: pp 283-290.

Hill DR, Campbell NJ, Shaw TM, Woodruff GN (1987). Autoradiographic localization and biochemical characterization of peripheral type CCK receptors in rat CNS using highly selective nonpeptide CCK antagonists. J Neurosci 7: pp 2967-2976.

Johnson NJ, Rodgers RJ (1996). Ethological analysis of cholecystokinin (CCKA and CCKB) receptor ligands in the elevated plusmaze test of anxiety in mice. Psychopharmacology (Berl) 124: pp 355-364.

Joseph A, Tang M, Mamiya T, Chen Q, Yang LL, Jiao J et al (2013). Temporal association of elevated cholecystokininergic tone and adolescent trauma is critical for posttraumatic stress disorderlike behavior in adult mice. Proc Natl Acad Sci USA 110: pp 6589-6594.

Josselyn SA, Frankland PW, Petrisano S, Bush DE, Yeomans JS, Vaccarino FJ (1995). The CCKB antagonist, L-365 260, attenuates fear-potentiated startle. Peptides 16: pp 1313-1315.

Kamprath K, Romo-Parra H, Haring M, Gaburro S, Doengi M, Lutz $B$ et al (2011). Short-term adaptation of conditioned fear responses through endocannabinoid signaling in the central amygdala. Neuropsychopharmacology 36: pp 652-663.

Karson MA, Whittington KC, Alger BE (2008). Cholecystokinin inhibits endocannabinoid-sensitive hippocampal IPSPs and stimulates others. Neuropharmacology 54: pp 117-128.

Katona I, Rancz EA, Acsady L, Ledent C, Mackie K, Hajos N et al (2001). Distribution of CB1 cannabinoid receptors in the amygdala and their role in the control of GABAergic transmission. J Neurosci 21: pp 9506-9518.
Kellner M, Yassouridis A, Jahn H, Wiedemann K (1997). Influence of clonidine on psychopathological, endocrine and respiratory effects of cholecystokinin tetrapeptide in patients with panic disorder. Psychopharmacology (Berl) 133: pp 55-61.

Kellner M, Wiedemann K, Yassouridis A, Levengood R, Guo LS, Holsboer F et al (2000). Behavioral and endocrine response to cholecystokinin tetrapeptide in patients with posttraumatic stress disorder. Biol Psychiatry 47: pp 107-111.

Kuhnert S, Meyer C, Koch M (2013). Involvement of cannabinoid receptors in the amygdala and prefrontal cortex of rats in fear learning, consolidation, retrieval and extinction. Behav Brain Res 250: pp 274-284.

Kuwahara T, Kudoh T, Nakano A, Yoshizaki H, Takamiya M, Nagase $\mathrm{H}$ et al (1993). Species specificity of pharmacological characteristics of CCK-B receptors. Neurosci Lett 158: pp 1-4.

Langhans N, Rindi G, Chiu M, Rehfeld JF, Ardman B, Beinborn M et al (1997). Abnormal gastric histology and decreased acid production in cholecystokinin-B/gastrin receptor-deficient mice. Gastroenterology 112: pp 280-286.

Larsson LI, Rehfeld JF (1979). Localization and molecular heterogeneity of cholecystokinin in the central and peripheral nervous system. Brain Res 165: pp 201-218.

Laviolette SR, Grace AA (2006). Cannabinoids Potentiate Emotional Learning Plasticity in Neurons of the Medial Prefrontal Cortex through Basolateral Amygdala Inputs. J Neurosci 26: pp $6458-6468$

LeDoux JE (2000). Emotion circuits in the brain. Annu Rev Neurosci 23: pp 155-184.

Lee SH, Soltesz I (2011). Requirement for CB1 but not GABAB receptors in the cholecystokinin mediated inhibition of GABA release from cholecystokinin expressing basket cells. J Physiol 589(Pt 4): pp 891-902.

Lee SY, Foldy C, Szabadics J, Soltesz I (2011). Cell-type-specific CCK2 receptor signaling underlies the cholecystokinin-mediated selective excitation of hippocampal parvalbumin-positive fastspiking basket cells. J Neurosci 31: pp 10993-11002.

Lein ES, Hawrylycz MJ, Ao N, Ayres M, Bensinger A, Bernard A et al (2007). Genome-wide atlas of gene expression in the adult mouse brain. Nature 445: pp 168-176.

Lin HC, Mao SC, Chen PS, Gean PW (2008). Chronic cannabinoid administration in vivo compromises extinction of fear memory. Learn Mem 15: pp 876-884.

Lin HC, Mao SC, Su CL, Gean PW (2009). The role of prefrontal cortex CB1 receptors in the modulation of fear memory. Cereb Cortex 19: pp 165-175.

Lin QS, Yang Q, Liu DD, Sun Z, Dang H, Liang J et al (2011). Hippocampal endocannabinoids play an important role in induction of long-term potentiation and regulation of contextual fear memory formation. Brain Res Bull 86: pp 139-145.

Manwell LA, Satvat E, Lang ST, Allen CP, Leri F, Parker LA (2009). FAAH inhibitor, URB-597, promotes extinction and $\mathrm{CB}(1)$ antagonist, SR141716, inhibits extinction of conditioned aversion produced by naloxone-precipitated morphine withdrawal, but not extinction of conditioned preference produced by morphine in rats. Pharmacol Biochem Behav 94: pp 154-162.

Maren S, Fanselow MS (1996). The amygdala and fear conditioning: has the nut been cracked? Neuron 16: pp 237-240.

Marsicano G, Wotjak CT, Azad SC, Bisogno T, Rammes G, Cascio MG et al (2002). The endogenous cannabinoid system controls extinction of aversive memories. Nature 418: pp 530-534.

Mascagni F, McDonald AJ (2003). Immunohistochemical characterization of cholecystokinin containing neurons in the rat basolateral amygdala. Brain Res 976: pp 171-184.

Matto V, Harro J, Allikmets L (1997). The effects of cholecystokinin $\mathrm{A}$ and $\mathrm{B}$ receptor antagonists on exploratory behaviour in the elevated zero-maze in rat. Neuropharmacology 36: pp 389-396.

McDonald AJ, Mascagni F (2001). Localization of the CB1 type cannabinoid receptor in the rat basolateral amygdala: high 
concentrations in a subpopulation of cholecystokinin-containing interneurons. Neuroscience 107: pp 641-652.

McDonald AJ, Mascagni F, Mania I, Rainnie DG (2005). Evidence for a perisomatic innervation of parvalbumin-containing interneurons by individual pyramidal cells in the basolateral amygdala. Brain Res 1035: pp 32-40.

Mechoulam R, Parker LA (2013). The endocannabinoid system and the brain. Annu Rev Psychol 64: pp 21-47.

Meis S, Munsch T, Sosulina L, Pape HC (2007). Postsynaptic mechanisms underlying responsiveness of amygdaloid neurons to cholecystokinin are mediated by a transient receptor potential-like current. Mol Cell Neurosci 35: pp 356-367.

Mellman TA, Davis GC (1985). Combat-related flashbacks in posttraumatic stress disorder: phenomenology and similarity to panic attacks. J Clin Psychiatry 46: pp 379-382.

Mercer LD, Beart PM (2004). Immunolocalization of CCK1R in rat brain using a new anti-peptide antibody. Neurosci Lett 359: pp 109-113.

Morisset J, Julien S, Laine J (2003). Localization of cholecystokinin receptor subtypes in the endocine pancreas. J Histochem Cytochem 51: pp 1501-1513.

Muller J, Corodimas KP, Fridel Z, LeDoux JE (1997). Functional inactivation of the lateral and basal nuclei of the amygdala by muscimol infusion prevents fear conditioning to an explicit conditioned stimulus and to contextual stimuli. Behav Neurosci 111: pp 683-691.

Muller JF, Mascagni F, McDonald AJ (2005). Coupled networks of parvalbumin-immunoreactive interneurons in the rat basolateral amygdala. J Neurosci 25: pp 7366-7376.

Myers KM, Davis M (2007). Mechanisms of fear extinction. Mol Psychiatry 12: pp 120-150.

Neumeister A, Normandin MD, Pietrzak RH, Piomelli D, Zheng MQ, Gujarro-Anton A et al (2013). Elevated brain cannabinoid CB1 receptor availability in post-traumatic stress disorder: a positron emission tomography study. Mol Psychiatry 18: pp 1034-1040.

Orio L, Crespo I, Lopez-Moreno JA, Reyes-Cabello C, Rodriguez de Fonseca F, Gomez de Heras R (2011). Additive effects of cannabinoid CB1 receptors blockade and cholecystokinin on feeding inhibition. Pharmacol Biochem Behav 98: pp 220-226.

Pertwee RG (1997). Pharmacology of cannabinoid CB1 and CB2 receptors. Pharmacol Ther 74: pp 129-180.

Plendl W, Wotjak CT (2010). Dissociation of within- and between-session extinction of conditioned fear. J Neurosci 30: pp 4990-4998.

Quirk GJ, Repa C, LeDoux JE (1995). Fear conditioning enhances short-latency auditory responses of lateral amygdala neurons: parallel recordings in the freely behaving rat. Neuron 15: pp 1029-1039.

Quirk GJ, Likhtik E, Pelletier JG, Pare D (2003). Stimulation of medial prefrontal cortex decreases the responsiveness of central amygdala output neurons. J Neurosci 23: pp 8800-8807.

Rasmussen K, Helton DR, Berger JE, Scearce E (1993). The CCK-B antagonist LY288513 blocks effects of diazepam withdrawal on auditory startle. Neuroreport 5: pp 154-156.

Raud S, Innos J, Abramov U, Reimets A, Koks S, Soosaar A et al (2005). Targeted invalidation of CCK2 receptor gene induces anxiolytic-like action in light-dark exploration, but not in fear conditioning test. Psychopharmacology (Berl) 181: pp 347-357.

Reich CG, Mohammadi MH, Alger BE (2008). Endocannabinoid modulation of fear responses: learning and state-dependent performance effects. J Psychopharmacol 22: pp 769-777.
Revel L, Mennuni L, Garofalo P, Makovec F (1998). CR 2945: a novel CCKB receptor antagonist with anxiolytic-like activity. Behav Pharmacol 9: pp 183-194.

Richard D, Guesdon B, Timofeeva E (2009). The brain endocannabinoid system in the regulation of energy balance. Best Pract Res Clin Endocrinol Metab 23: pp 17-32.

Riebe CJ, Pamplona FA, Kamprath K, Wotjak CT (2012). Fear relief-toward a new conceptual frame work and what endocannabinoids gotta do with it. Neuroscience 204: pp 159-185.

Robbe D, Montgomery SM, Thome A, Rueda-Orozco PE, McNaughton BL, Buzsaki G (2006). Cannabinoids reveal importance of spike timing coordination in hippocampal function. Nat Neurosci 9: pp 1526-1533.

Rooman I, Lardon J, Flamez D, Schuit F, Bouwens L (2001). Mitogenic effect of gastrin and expression of gastrin receptors in duct-like cells of rat pancreas. Gastroenterology 121: pp 940-949.

Ryan SJ, Ehrlich DE, Jasnow AM, Daftary S, Madsen TE, Rainnie DG (2012). Spike-timing precision and neuronal synchrony are enhanced by an interaction between synaptic inhibition and membrane oscillations in the amygdala. PLoS One 7: pp e35320.

Schlicker E, Kathmann M (2001). Modulation of transmitter release via presynaptic cannabinoid receptors. Trends Pharmacol Sci 22: pp 565-572.

Sekiguchi R, Moroji T (1986). A comparative study on characterization and distribution of cholecystokinin binding sites among the rat, mouse and guinea pig brain. Brain Res 399: pp 271-281.

Shlik J, Aluoja A, Vasar V, Vasar E, Podar T, Bradwejn J (1997). Effects of citalopram treatment on behavioural, cardiovascular and neuroendocrine response to cholecystokinin tetrapeptide challenge in patients with panic disorder. J Psychiatry Neurosci 22: pp 332-340.

Tsou K, Brown S, Sanudo-Pena MC, Mackie K, Walker JM (1998). Immunohistochemical distribution of cannabinoid CB1 receptors in the rat central nervous system. Neuroscience 83: pp 393-411.

Tsutsumi T, Akiyoshi J, Isogawa K, Kohno Y, Hikichi T, Nagayama H (1999). Suppression of conditioned fear by administration of CCKB receptor antagonist PD135158. Neuropeptides 33: pp 483-486.

Tzavara ET, Davis RJ, Perry KW, Li X, Salhoff C, Bymaster FP et al (2003). The CB1 receptor antagonist SR141716A selectively increases monoaminergic neurotransmission in the medial prefrontal cortex: implications for therapeutic actions. $\mathrm{Br} \mathrm{J}$ Pharmacol 138: pp 544-553.

Uriguen L, Garcia-Gutierrez MS, Manzanares J (2011). Decreased GABAA and GABAB receptor functional activity in cannabinoid CB1 receptor knockout mice. J Psychopharmacol 25: pp 105-110.

Vanderhaeghen JJ, Signeau JC, Gepts W (1975). New peptide in the vertebrate CNS reacting with antigastrin antibodies. Nature 257: pp 604-605.

Voikar V, Polus A, Vasar E, Rauvala H (2005). Long-term individual housing in $\mathrm{C} 57 \mathrm{BL} / 6 \mathrm{~J}$ and $\mathrm{DBA} / 2$ mice: assessment of behavioral consequences. Genes Brain Behav 4: pp 240-252.

Woodruff AR, Sah P (2007). Inhibition and synchronization of basal amygdala principal neuron spiking by parvalbuminpositive interneurons. J Neurophysiol 98: pp 2956-2961.

Yoshida T, Uchigashima M, Yamasaki M, Katona I, Yamazaki M, Sakimura K et al (2011). Unique inhibitory synapse with particularly rich endocannabinoid signaling machinery on pyramidal neurons in basal amygdaloid nucleus. Proc Natl Acad Sci USA 108: pp 3059-3064.

Zarbin MA, Innis RB, Wamsley JK, Snyder SH, Kuhar MJ (1983). Autoradiographic localization of cholecystokinin receptors in rodent brain. J Neurosci 3: pp 877-906.

Supplementary Information accompanies the paper on the Neuropsychopharmacology website (http://www.nature.com/npp) 